\title{
Konotativno značenje socijalno i politički relevantnih pojmova kao indikator društvene klime - longitudinalna studija u Srbiji
}

\author{
NEBOJŠA PETROVIĆ, BORA KUZMANOVIĆ
}

Filozofski fakultet, Univerzitet u Beogradu

\begin{abstract}
Sažetak
Ovaj rad predstavlja komparativnu studiju sačinjenu od četiri istraživanja obavljena u periodu od 1997. do 2015. godine. U njima se ispituje konotativno značenje politički relevantnih pojmova kod učenika završnih razreda raznih vrsta srednjih škola. Kako je konotativno značenje ono dodatno, emocionalno obojeno značenje, ta obojenost potiče iz socijalne sredine i duha vremena, te je sa promenama ovoga značenja moguće pratiti i promene dominantnih društvenih vrednosti i društvene klime. Uzorak je činilo ukupno oko 750 učenika koji su u četiri vremenske tačke (poduzorci su u tim tačkama bili ujednačeni po socijalno-demografskim karakteristikama) procenjivali sledeće pojmove: nacija, nacionalizam, socijalizam, vođa, demokratija, mir, levica, desnica, sadašnjost i budućnost. Svaki od pojmova ispitan je Ozgudovom skalom semantičkog diferencijala preko 12 opozitnih parova prideva poput ružan-lep ili bezvredan-vredan. Rezultati su pokazali značajna variranja kako na 12 pridevskih parova na svakom pojmu u jednoj vremenskoj tački - što daje suptilniji profil značenja nego što bi dala opšta, jedinstvena ocena pojmova poput demokratije ili nacije - tako i u četiri vremenske tačke. Variranja tokom godina daju indicije o promeni društvene klime i vrednosti, barem u generaciji mladih, u ovom po Srbiju turbulentnom razdoblju od dve decenije.
\end{abstract}

Ključne riječi: konotativno značenje pojmova, pojmovi, mladi, društvo, promena društvene klime

\section{Uvod}

Brojne reči koje su često korišćene u javnoj komunikaciji, posebno u političkom domenu, karakterisane su dodatnim značenjem. Ovaj dodatak osnovnom značenju je zasnovan u emocionalnom aspektu reči, koje su nekada predimenzionisane i u upotrebnom jeziku. Međutim, ovo dodatno značenje nije trajna osobenost, već je 
pre promenljivo i zavisi od ličnog i grupnog iskustva, koja opet zavise od socijalne sredine i duha vremena. Uzmimo za primer reč boljševik. Tokom Drugog svetskog rata ili posle njega, kod pripadnika partizanskog pokreta, ta reč je nesumnjivo bila svetla i blistala kao sunce, odnosno bila izrazito pozitivno emocionalno obojena. U periodu posle urušavanja socijalističkih poredaka 1989., kada biste nekoga, posebno u centralnoj i istočnoj Evropi, okarakterisali kao boljševika, to je često bilo gore od psovke, odnosno reč je bila izrazito negativno emocionalno obojena. U današnje vreme, kada biste mladim ljudima pomenuli reč boljševik, najveći broj njih ne bi ni razumeo o čemu pričate, pa bi reakcija izostala ili bi bila veoma slaba. Dakle društvene okolnosti boje određene pojmove i izučavajući tu obojenost možemo doći i do odgovora o onome ko je bojio i zašto je izabrao baš tu nijansu. Naravno, uvek se mogu pronaći neke subgrupe u okviru populacija koje na stvari gledaju drugačije od većine, ali postoje i neki zajednički elementi koje dele gotovo svi članovi društva i koji se u literaturi pojavljuju pod pojmovima od socijalni karakter (From, 2016 [1941]) do zajednička uverenja (Bar-Tal, 2000). Oni ne nastaju voljom jedne osobe ili grupe, nego procesima "pregovaranja" unutar jednog društva i predstavljaju rezultantu različitih faktora koji ih oblikuju različitim stepenima uticaja (kroz obrazovanje, popularnu kulturu, svakodnevne susrete, u poslednje vreme društvene mreže i slično). U čuvenom Ozgudovom atlasu značenja nisu bile uvek nužne politički relevantne reči. Nekada i prosta boja ima političko značenje. Daleko pre političkih promena u prvoj dekadi XX veka koje su postale poznate kao "obojene revolucije" (severna Afrika, Gruzija, Ukrajina), utvrđeno je naime da u velikoj većini zemalja ljudi najpozitivnije emocionalno reaguju na plavu boju. U muslimanskom svetu to je svakako bila zelena. Jedina socijalistička država koja je tada bila uključena u istraživanje bila je Jugoslavija, a prevagu je odnela, dakako, crvena boja (Osgood, 1964).

Stoga, otkrivajući reči koje su emocionalno obremenjene u određenom društvu u nekom vremenskom trenutku, indirektno možemo utvrditi, između ostalog, i manifestacije Zeitgeista, duha vremena. U periodu radikalnih društvenih promena, i mnoge psihološke promene su brze i značajne (Biro i sar., 2002). Glavni cilj ovog istraživanja je da obezbedi svedočanstvo o tom duhu vremena u poslednjih 20 godina u Srbiji preko ispitivanja konotativnog značenja (i promena) nekih termina često korišćenih u političkom životu u Srbiji na ovaj, za ovakav cilj inovativan način. U socijalnopsihološkom smislu, semantički diferencijal se metodološki posmatra i kao indirektna tehnika za merenje stavova, ali mogli bismo reći i ukupnog doživljaja jednog pojma, koji uključuje i strah, (ne)sigurnost, (ne)zadovoljstvo načinom ostvarivanja određenog društvenog cilja ili ideala.

Merenje značenja je započelo još 1920-ih godina. Započelo je merenjem fizioloških reakcija, potom raznih percepcija, asocijacija i slično. Ideja o skaliranju 
značenja dolazi 1940-ih od Čarlsa Ozguda (Charles Osgood), koga je nekoliko decenija istraživanja dovelo do razvoja tehnike poznate kao semantički diferencijal (Osgood, 1952). Značajnu ulogu merenje značenja ima i u ruskoj psihologiji (npr. Petrenko, 1993).

Poznato je da reči imaju dve vrste značenja. Denotativno značenje je primarno, specifično značenje reči (najčešće ono koje je objašnjeno u rečnicima). Konotativno značenje je ono pridodato, i ono je proizvod iskustva pojedinca ili grupe sa pojavom na koju se reč odnosi, ili sa samom reči. Stoga je ono, uglavnom, afektivno po svojoj prirodi.

Ozgud, Suci i Tanenbaum (1957) zastupaju gledište da je semantički diferencijal "psihološka alatka, načinjena da meri... značenje...". Oni ističu da "semantički diferencijal otkriva konotativni aspekt značenja direktno, pa potom... denotativni aspekt" (ibid.: 290). Predloženi instrument je kombinacija asocijacija i skaliranja. Ovo je indirektan metod koji se poredi sa Ozgudovim testom inteligencije jer obezbeđuje objektivne i korisne informacije, mada ne mere direktno ono što je predmet istraživanja. Za razliku od testova inteligencije koji tretiraju predmet svog merenja kao skor distribuiran duž jednog kontinuuma (IQ skor), Ozgudova polazna tačka je da se značenje menja na većem broju dimenzija, odnosno da ga ne možemo svesti na jedan kontinuum.

Sam termin diferencijal potiče iz činjenice da instrument meri diferencijalne konotacije kojima ispitanici opažaju objekat. Skala semantičkog diferencijala se sastoji od serija bipolarnih skala, odnosno parova opozitnih prideva, gde jedan pridev označava jednu stranu skale (na primer “dobar"), dok je suprotni pridev ("loš”) na drugom kraju skale. Ispitanici procenjuju pojam koji je ispisan na vrhu, zaokružujući određeni broj između svakog para prideva (najčešće od -3 do +3 ), koji predstavlja njihovo mišljenje o najboljem mestu na skali za dati pojam. Nobelovac Danijel Kaneman je radio svoju doktorsku disertaciju na temu semantičkog diferencijala. ${ }^{1}$

Brojnim faktorskim analizama (pre svega u SAD, a potom i u drugim zemljama), Ozgud i saradnici su utvrdili tri najvažnija faktora konotativnog (afektivnog) značenja: evaluacija, potencija i aktivitet. Utvrđeno je da je evaluativna dimenzija najvažnija i ona kao faktor objašnjava ubedljivo najveći procenat varijanse (Osgood, Suci i Tannebaum, 1957). Tipični parovi prideva na ovoj dimenziji su: dobar-loš, lep-ružan, čist-prljav, pošten-nepošten itd.

Ono što je ovde posebno važno jeste činjenica da se ovom tehnikom mogu meriti stavovi (Havelka, Kuzmanović i Popadić, 1995; Himmelfarb, 1993). I tri prvobitna autora eksplicitno ukazuju na evaluativnu dimenziju, tvrdeći da "je izvodlji-

${ }^{1}$ https://www.researchgate.net/publication/33868425_An_analytical_model_of_the_semantic_differential_microform. 
vo identifikovati 'stav' kao jednu od glavnih dimenzija značenja uopšte" (Osgood, Suci i Tannebaum, 1957: 189). Pod značenjem jednog pojma smatra se njegovo mesto u multidimenzionalnom prostoru, a stav prema datom pojmu je projekcija te tačke značenja na jednu od dimenzija značenja - onu evaluativnu. Ovo je u skladu sa glavnom tradicijom sociopsiholoških istraživanja gde je stav prvobitno bio shvatan pre svega kao tačka na dimenziji "za ili protiv". Danas se obično stavovi prema objektima najčešće mere tako što ispitanici označavaju stepen slaganja ili neslaganja sa serijom tvrdnji (Likert, 1932). Ispitivanje semantičkim diferencijalom ispitanicima je obično predstavljeno kao merenje značenja, pre nego stavova, i stoga se ova tehnika obično ubraja u indirektne (ili poludirektne) tehnike za merenje stavova (Snider i Osgood, 1969; Osgood, May i Miron, 1975).

Tannenbaum (1956) je bio među prvima koji je koristio ovu tehniku za merenje stavova prema određenim pojmovima, a kasnije su to činili i mnogi drugi. "Validnost semantičkog diferencijala kao skale za merenje stavova je visoka, što je zasnovano na visokim korelacijama sa skorovima na tradicionalnim Terstonovim, Likertovim i Gutmanovim tipovima skala" (Brinton, 1961: 289).

Ako izabrani pridevski parovi imaju visoko zasićenje na evaluativnom faktoru, može se očekivati da dve grupe formirane na bazi stavova (oni sa pozitivnim i oni sa negativnim stavovima) pokazuju velike razlike u aritmetičkim sredinama na skalama sa tim parovima prideva. Brinton, međutim, ističe i da značenje i evaluacije prideva variraju od pojma do pojma. On daje primer "smrtne kazne" koja bi, kada bismo procenjivali na dimenziji "lep-ružan", mogla da izgubi značaj u smislu evaluiranja stava. U takvom slučaju pre bi moglo biti objašnjeno denotativno značenje. Pominje se i pojam škole koja zaista može biti čista ili prljava, a da to nema nikakvo preneseno značenje.

Mnogi obični ljudi i ne znaju pravo (denotativno) značenje određenih pojmova (na primer "levica" i "desnica" u ovom istraživanju, koji su i denotativno menjani u proteklih 200 godina, ili pojam "demokratija”, koji je od klasičnih grčkih mislilaca do danas neretko razumevan na različite načine), ali to ne znači da takvi pojmovi i dalje ne izazivaju emocionalni odgovor (koji je posebno pogodan za manipulaciju). U stvari, moglo bi se reći da za mnoge ljude nema precizne granice između denotativnog i konotativnog značenja, već da tretiraju oba kao jedinstvenu celinu. Granice obično postavljaju istraživači, neizostavno veštački, da bi detaljnije analizirali jedan fenomen. No afektivno značenje jednog pojma svakako se može dobiti dobrom selekcijom i pripremom skale semantičkog diferencijala, a time i stav pojedinca prema objektu na koji određena reč referira. Čini nam se i više od samog stava, da ovom tehnikom zahvatamo ukupan doživljaj jednog pojma koji pored stava uključuje i strahove, nesigurnosti vezane za pojavu na koju se pojam odnosi, kao i zadovoljstvo odnosno nezadovoljstvo načinom na koji se određena ideja, program ili pojava ostvaruje. 


\section{Elementi društveno-političke situacije u Srbiji od 90-ih do danas}

Konotativno značenje pojmova prikazanih u ovom istraživanju utvrđivano je četiri puta u periodu od dve decenije, od sredine 1990-ih godina pa do sredine ove decenije. To je bilo veoma turbulentno razdoblje u Srbiji, koje je nastavak još turbulentnijih, po obimu i sadržaju moglo bi se reći revolucionarnih promena u društvu. Naime početkom 1990-ih iz korena se menja skoro sve što se može promeniti u jednom društvu. Na mestu socijalističke i nesvrstane Jugoslavije pojavljuje se više novih država, a raspad zemlje praćen je veoma okrutnim ratovima, sa brojnim žrtvama i razaranjima, nakon kojih ostaju i snažni resantimani prema drugim narodima koji su sve do početka sukoba 1990-ih živeli u uglavnom dobrim međunacionalnim odnosima (Bačević i dr., 1991; Lazaroski, 1994), a ostaju i razrušene zgrade i upropašćena industrija, te zaustavljen razvoj u najdinamičnijoj deceniji razvoja u svetu. Pored potpuno narušenih međuetničkih odnosa, menja se i društveno uređenje i proklamovane vrednosti kojima društvo teži. Srbija živi pod sankcijama Ujedinjenih nacija, koje, između ostalog, izazivaju i jednu od najvećih inflacija u XX veku. Sve ovo značajno determiniše svet i društvenu svest mladih ljudi. U drugoj polovini 1990-ih prestaju međuetnički sukobi na području BiH i Hrvatske, ali se krajem decenije javljaju novi ratni sukobi - pre svega bombardovanje tadašnje SR Jugoslavije od strane NATO pakta, kao i sukobi u Severnoj Makedoniji. U jesen 2000. godine dolazi do radikalne promene vlasti u Srbiji (prva pobeda opozicije nakon Drugog svetskog rata), gde umesto donekle reformisane partije iz vremena socijalizma, koja je bila dominantna i tokom ratnih sukoba, dolazi na vlast skupina do tada opozicionih stranaka širokog ideološkog spektra, ali jasnih protivnika dotadašnjeg režima, koji čine neke značajne korake koji omogućavaju promene na bolje u spoljnoj politici i napredak u ekonomskoj sferi (ulazak Srbije u UN, povećavanje plata i rast nacionalnog dohotka i sl.). Ta raznorodna grupacija stranaka biva ubrzo ophrvana unutrašnjim sukobima, koji uz nemirenje delova prethodne vlasti sa novim stanjem dovode do niza političkih trvenja, koja eskaliraju sa ubistvom predsednika Vlade 2003. godine, a nastavljaju se nizom promena unutar te grupacije i njenog viđenja razvoja zemlje, osnovnih vrednosti i odnosa prema zaostavštini iz 1990-ih i prema međunarodnoj zajednici. Sve te brzo menjajuće okolnosti i politički potresi ogledaju se i u stavovima javnog mnenja prema bitnim društvenim pitanjima sadašnjosti i budućnosti, ali i gledanju na prošlost (gotovo svake godine se donekle menjaju lekcije o novijoj istoriji Srbije u školskim udžbenicima). Vođe dve najveće vladajuće stranke iz 1990-ih sudi Tribunal u Hagu kao i brojnim najvišim vojnim i policijskim starešinama. Srbija pravi prve korake ka Evropskoj uniji i stiže do statusa kandidata za članstvo. Početkom druge decenije ovoga stoleća, čak i delovi vladajućih elita pozivaju na pokazivanje nezadovoljstva i otpora vlasti izlaskom na izbore, ali ne i glasanjem - jer nisu ni za opoziciju. Godine 2012. tadašnja opozicija koju su činile 
donekle reformisane vladajuće stranke iz 1990-ih ponovo dolazi na vlast. U ovom veku prvo Crna Gora proglašava nezavisnost koju Srbija zvanično priznaje, a kasnije to čini i Kosovo. Ovu potonju nezavisnost otprilike polovina sveta priznaje, a druga polovina, uključujući i Srbiju, osporava. To dovodi do kolizije između težnji Srbije da pristupi Evropskoj uniji, i pritisaka iz Unije da Srbija prizna Kosovo. Na individualnom političkom planu, mnogi političari menjaju strane, te čak neki od najbližih saradnika premijera ubijenog 2003. postaju funkcioneri sadašnjih vlasti. Sve te objektivne promene praćene su manjim ili većim isticanjem važnosti i značaja određenih društvenih vrednosti i čitave atmosfere u društvu. Upravo stoga, čini nam se veoma značajnim da utvrdimo te promene i preko konotativnog značenja politički bitnih pojmova, u četiri vremenske tačke.

\section{Metod}

Glavni cilj ovog istraživanja je, stoga, da se utvrdi konotativno značenje odabranih društveno i politički relevantnih pojmova i na osnovu toga, u skladu sa prethodno opisanim, pokaže kako takvo značenje korespondira sa duhom vremena, odnosno dominantnom atmosferom u društvu. Posebno nas zanimaju promene konotativnih značenja reči u četiri odabrane vremenske tačke: 1997., 2004., 2011. i 2015. godine. Rezultati prva dva istraživanja su objavljeni, i to kao osnovna analiza rezultata iz 1997. (Petrović i Kuzmanović, 1998), a drugo kao poređenje prve dve studije (Kuzmanović i Petrović, 2005), u kojima su već utvrđene neke promene, što je podstaklo i nova istraživanja u narednoj deceniji. Dodatni cilj, koji je postavljen ali ovde neće biti detaljno elaboriran, bio je da se utvrdi da li te mape značenja variraju po bitnim karakteristikama uzorka, koje su uključivale: vrstu škole, pol, obrazovanje roditelja (i preko toga socio-kulturni status), stepen religioznosti, autoritarnosti, zainteresovanosti za politiku, važnosti pripadanja sopstvenoj naciji i preferencije brzine i obima društvenih promena.

Izabrani uzorak stimulusa, politički relevantnih pojmova, uključivao je sledeće reči: demokratija, nacija, nacionalizam, socijalizam, vođa, mir, (politička) levica i desnica, kao i vremenske odrednice sadašnjost i budućnost (prošlost je korišćena u prvim istraživanjima, ali je potom izostavljena jer se pokazalo da ispitanici nemaju ni približno isti referentni okvir, npr. neki su referisali na bližu, a drugi na dalju). U nekim od istraživanja je proveravano i znanje ispitanika o denotativnom (osnovnom) značenju nekih pojmova.

\section{Instrument}

Korišćeni instrument je bio skala semantičkog diferencijala. U odabiru prideva koji će biti uključeni u studiju vodilo se računa o nekoliko kriterijuma. Početna tačka je bila lista od 50 parova prideva iz Ozgudovih i još nekih ranijih studija, sa koje 
su birani pre svega oni koji primarno imaju visoko zasićenje na faktoru evaluacije. Izabrani su sledeći parovi prideva: važan-nevažan, stabilan-nestabilan, prijatan-neprijatan, jak-slab, lep-ružan, dobar-loš, nesiguran-siguran, čist-prljav, pozitivan-negativan, pravedan-nepravedan, poželjan-nepoželjan, blizak-dalek.

Skala je bila sedmostepena, od -3 do +3 , i prvopomenuti ("pozitivni") pridevi su bili sa desne strane, a potonji sa leve strane skale, na primer: loš $-3-2-10+1+2+3$ dobar.

\section{Uzorak}

Istraživanje je obavljeno $\mathrm{u}$ četiri vremenske tačke: $\mathrm{u}$ Beogradu, svaki put $\mathrm{u}$ istim srednjim školama: a) gimnazijama, b) stručnim četvorogodišnjim školama i c) školama za rad u proizvodnji - za grafički dizajn i dizajn kože. Ukupan uzorak se sastojao od oko 750 učenika uglavnom četvrtog razreda (osim kad je smer bio trogodišnji), po 160-200 u svakoj vremenskoj tački, odnosno po 60-ak (po trećina) po tipu škole. Dakle radilo se o različitim ljudima, odnosno generacijama učenika, koji su pohađali iste škole, gde su gotovo svi u trenutku ispitivanja imali 18 ili 19 godina.

Mada relativno ograničen uzorak ne dozvoljava velike generalizacije rezultata, treba istaći da je Ozgud za ispitanike imao isključivo dečake iz gradskih sredina (Osgood, 1964). Sa druge strane, činjenica da su ispitanici mladi je interesantna i zbog toga što je taj životni period za njih formativni period koji koincidira sa društvenim turbulencijama i dramatičnim promenama od politike do tehnološke revolucije (npr. u prvoj ispitanoj generaciji niko nije imao mobilne telefone, dok poslednja generacija spada u tzv. digitalne nomade koji se najčešće ne odvajaju od mobilnog telefona ni kada spavaju). Blanuša i Šiber (2011: 86) detaljno obrazlažu mnoštvo važnih razloga interesa za mlade, od toga da oni po svom psihološkom razvoju i društvenom statusu jasno izražavaju društvene probleme i antagonizme, preko delovanja ka budućnosti, do toga da zbog sopstvene veće fleksibilnosti mogu postati i agensi socijalizacije svojih roditelja.

Način korišćenja sve četiri studije bi, strogo uzevši, trebalo nazvati kvazi-longitudinalni. Naime u četiri vremenske tačke nisu bili isti ljudi koji bi bili praćeni kroz određeno vreme, nego svaki put uzorak su činile osobe sa istim mestom u društvenoj strukturi i istim socio-demografskim varijablama: dakle uvek učenici završnih razreda, istih srednjih škola. Ovo nije klasično longitudinalno istraživanje, u kome se prate isti ljudi, a koje bi imalo neke mane jer svi ljudi menjaju svoje stavove, poglede na život i svet oko sebe i pod uticajem životnih iskustava i starenja. Namesto toga, izabrano je kvazi-longitudinalno istraživanje sa četiri ujednačene grupe (po godinama, socijalnom i etničkom poreklu, tipu škole i sl.) koje su ispitivane u različitim okolnostima, gde je dominantna društvena klima - odnosno duh vremena - predstavljala date "okolnosti". 


\section{Rezultati}

U ovom radu, podvucimo to još jednom, ispitivani su prosečni doživljaji pojedinih reči u određenim generacijama, i poređeni su na agregatnom nivou proseci tih generacija kroz vreme. Valja imati na umu da uvek postoje veća ili manja odstupanja u rezultatima u okviru uzorka. Stoga se može dogoditi da prosečno neku reč doživi neutralno homogen uzorak u kome skoro svi članovi tu reč doživljavaju neutralno, ali i duboko polarizovan uzorak u kome polovina ispitanih tu reč doživljava veoma pozitivno, a druga polovina negativno. Zbog toga ćemo, na mestima gde je to neizostavno, ukazati i na mere raspršenja rezultata preko standardnih devijacija dobijenih proseka. Svi odgovori su rekodirani u raspon 1 do 7 , gde je 4 neutralna tačka. Dakle rezultati ispod 4 imaju negativnu valencu, dok oni iznad ukazuju da se ispitanik o datom pojmu izjasnio bliže pozitivnom nego negativnom pridevu u datom paru.

Grafikon 1. Nacija

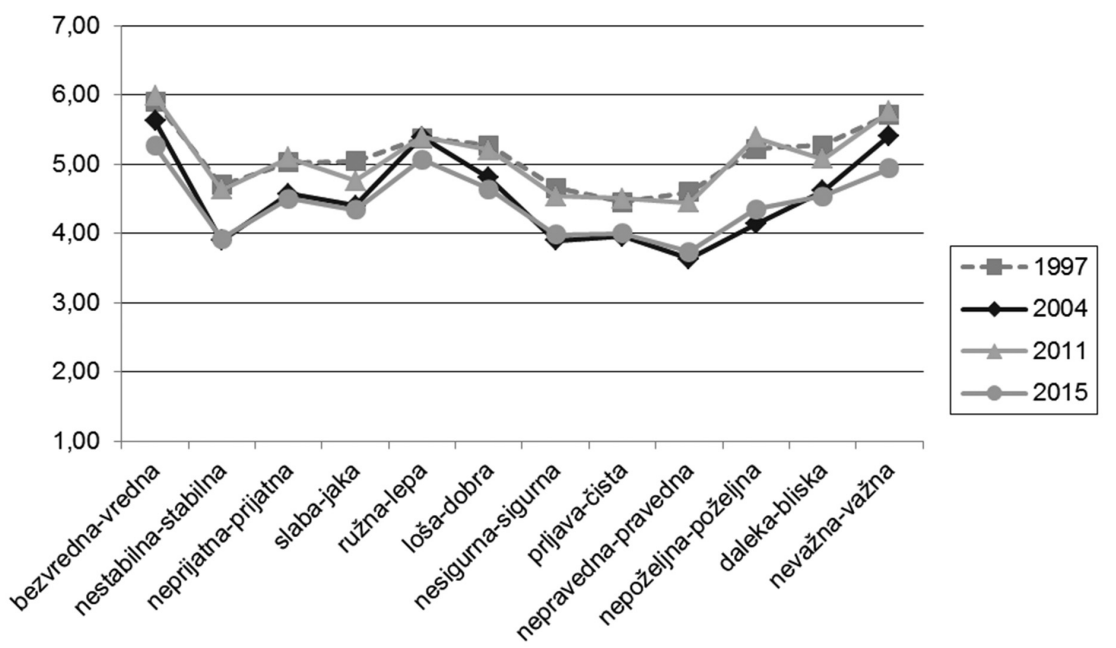

Nacija je u ovom istraživanju i u percepciji ispitanika pre svega viđena u okviru "nemačkog" klasičnog shvatanja nacije kao etničke grupe (za razliku od "francuskog", građanskog shvatanja). Zbog niza dilema u određivanju nacije i nacionalnog identiteta (Milošević-Đorđević, 2007) izvršili smo i dodatne provere; u jednom od istraživanja tražili smo od ispitanika da nam objasne šta podrazumevaju pod nacijom i još nekoliko ispitanih pojmova. Nacija je gotovo uvek identifikovana sa etničkom grupom. Kada razmatramo pojam nacije, moramo imati u vidu dve stvari. Prvo, da je tokom 1990-ih u ovom području buktalo nekoliko ratova u kojima su glavni protagonisti bile etničke grupe, dakle etnički sukobi. Takvi sukobi pojačavaju značaj vlastite grupe, unutargrupnu pristrasnost i time povećavanju negativan od- 
nos prema drugim grupama, na emocionalnom, kognitivnom i ponašajnom nivou, najčešće kroz predrasude, stereotipije i diskriminaciju. Druga važna stvar jeste da nacija uvek, a posebno u teškim okolnostima, kao grupa kojoj pripadamo ima i neke funkcionalne uloge u životima ljudi. Privrženost članova grupama kojima pripadaju može se naći među članovima svih grupa, i ona je u vezi sa pozitivnom evaluacijom sopstvene grupe i emocijama i uverenjima koji prenose sadržaje pripadanja, ljubavi, lojalnosti, ponosa i brige (Bar-Tal, 1997).

U takvim okolnostima nacija je ocenjena različito kako po pojedinim dimenzijama tako i tokom vremena. Velika većina ocena se nalazi u pozitivnom delu skale, a neke od ocena su veoma visoke. Nacija je u svakoj vremenskoj tački viđena kao vredna i važna (ocene dostižu liniju 6), kao i lepa (prelaze liniju 5). Pored toga, ispitanici iz različitih generacija se slažu i da je nacija dobra, jaka, bliska i prijatna (pozitivne ocene u sve četiri studije). Na osnovu ovih ocena možemo pretpostaviti da je nacija kod naših ispitanika u svim generacijama viđena kao nešto čemu pripadamo, $i$ što treba čuvati, te se stoga i pokazalo da je vredna i važna, čime se održava pozitivan socijalni identitet (Tajfel i Turner, 1979). Ispitanici je, naravno, ne vide idealistički, već je ocenjena u mnogo manjem stepenu kao stabilna, čista i pravedna. Da li je nacija viđena kao nepravedna, odnosno prosečno ocenjena na dimenziji pravedna-nepravedna zbog toga što je sama takva (čemu u prilog ide i nizak prosek na dimenziji prljava-čista), ili nije pravedno kroz kakve probleme prolazi, te međunacionalne interakcije nisu uvek čiste - ne možemo tvrditi samo na osnovu primene ove tehnike. Poredeći vremenske periode možemo primetiti da je nacija u dve vremenske tačke - 2004. i 2015. - po nekim pridevima (poželjna, pravedna, sigurna, čista) ocenjena manje pozitivno nego 1997. i 2011. Pokušaćemo da damo interpretaciju tih rezultata. Za prvo istraživanje, koje je proisteklo nedugo po okončanju ratova u $\mathrm{BiH}$ i Hrvatskoj, dok je još bila veoma prisutna polarizacija i demarkacija u odnosu na druge narode, i viši rezultati na svim dimenzijama su bili očekivani. Godine 2011., u periodu nakon neispunjenih očekivanja od promena koje su se desile deceniju ranije, delom i kao deo opšte retradicionalizacije zbog neispunjenih (bar ne brzo) očekivanja liberalne globalizacije, neki elementi ocene nacije takođe dobijaju na značaju. Sa druge strane, iako je nacija kao pojam generalno pozitivno ocenjen, po navedenim primerima je ocenjen nešto lošije 2004. godine, u vreme još uvek značajno drugačije društvene atmosfere podstaknute promenama 2000. koje su, između ostalog, dovodile u pitanje pojedine bitne vrednosti iz prethodne decenije. Ovde se možda jasno vidi ambivalentnost efekata tih promena, nacija je i dalje vredna i važna (mada nešto manje nego ranije), i dalje je lepa kao i ranije, ali je ipak mnogo manje pravedna, čista, sigurna i stabilna. Što se tiče rezultata iz 2015., tu nam se čini da objašnjenje pre leži u sumnji mladih generacija da se išta može suštinski promeniti na bolje (te indikatore videćemo u oceni budućnosti) i u potpunom pomeranju fokusa mladih sa (ionako slabe) vezanosti za društveno-političke 
aspekte života ka uznapredovalim tehnologijama koje konstruišu nove realnosti za sve građane. Mogli bismo to okarakterisati kao tendenciju analognu "kraju istorije", ali ne zbog pobede određene ideologije, već zbog pobede nadmoćne tehnologije (Harari, 2019: 330-336), ili je naprosto reč o alijenaciji. No mora se ponoviti da ova tendencija nije preterana, nego se tek vide njene naznake, i da je pojam nacije još uvek, u proseku, veoma bitan za mladu generaciju u Srbiji.

Grafikon 2. Nacionalizam

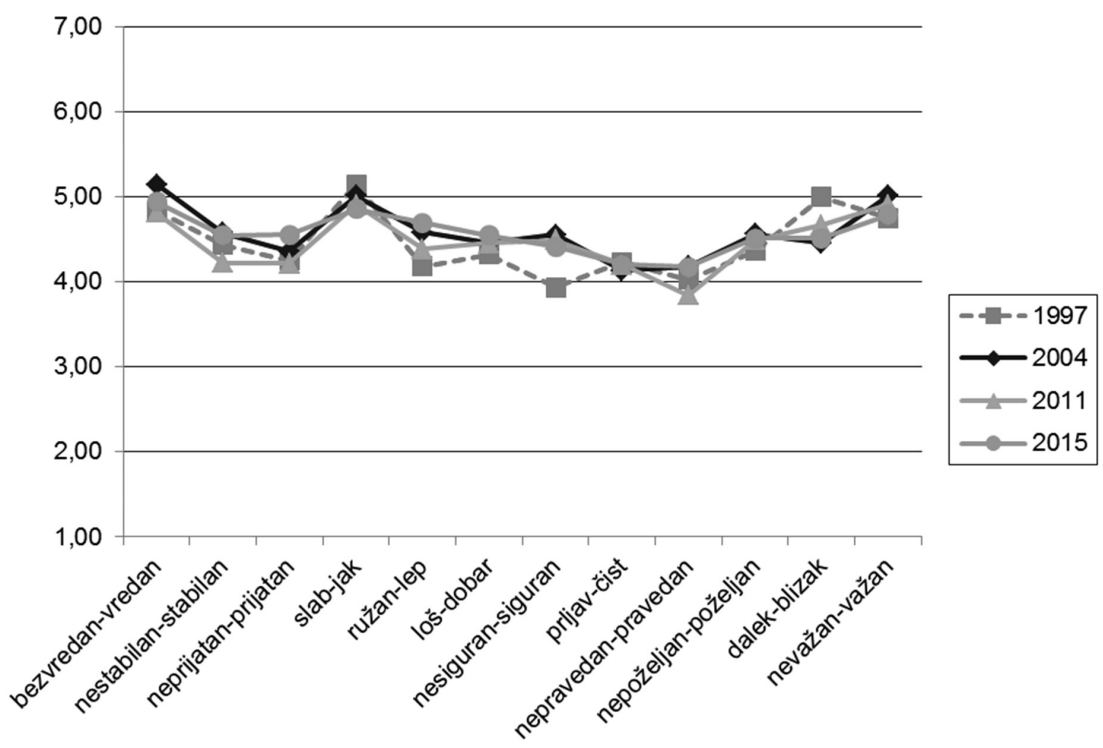

Nacionalizam se u literaturi gotovo isključivo smatra negativnim fenomenom, za razliku od patriotizma koji ima i pozitivne aspekte. Međutim, u Srbiji je, nakon perioda u socijalizmu kada je nacionalizam bio izrazito negativno vrednovan, od kraja 1980-ih nacionalizmu u javnom diskursu neretko davana pozitivna funkcija, koja je često izjednačavana sa patriotizmom. Ne da je dobro mrzeti druge narode, nego je nacionalizam veoma često definisan kao ljubav prema sopstvenom narodu, ne mrzeći druge, dakle kao istaknuta, a ne isključiva nacionalna vezanost (Guetzkow, 1955; Rot i Havelka, 1973). U jednoj od studija ispitanike smo pitali i da daju definiciju svakog pojma, i upravo pomenuta (sa manjim varijacijama) je bila najčešći odgovor kod pojma nacionalizam. Nacionalizam definisan kao šovinizam gotovo uopšte nije pominjan u odgovorima. Iako je kod nekih stranaka i vođa i njihovih sledbenika postojao nacionalizam u šovinističkom i isključivom smislu, ovu dominantno istaknutu nacionalnu vezanost moramo imati u vidu kada posmatramo 
dati grafikon. Gotovo je neverovatno da pored relativno burnih promena u gotovo dve decenije, pre svega vezanih za nacionalna pitanja i nacionalizam, pored različitih nivoa promocije nacionalizma, šovinizma, kosmopolitizma, hvaljenja i kuđenja, ovaj pojam sve četiri generacije vide, u proseku, gotovo na identičan način. Zanimljivo je, možda donekle i društveno opasno, da nacionalizam u proseku nije viđen kao negativan fenomen, iako ne ni previše pozitivan (gotovo sve ocene su u prvoj, najblažoj pozitivnoj trećini). Nacionalizam je pre svega viđen kao vredan, jak i važan, ali ne toliko prijatan niti pravedan. Ovo je veoma drugačiji rezultat od onih dobijenih krajem 1980-ih (Flere, 1986: 133) na omladini Jugoslavije (drugom metodom), gde je kod $12 \%$ tadašnjih omladinaca pronađeno odsustvo bilo kakve nacionalne vezanosti, slaba je karakterisala oko $44 \%$ ispitanika, srednja oko $42 \%$, a snažna samo $2,3 \%$, dok ekstremna gotovo da nije ni postojala, svega $0,1 \%$. Uvek moramo imati u vidu da je reč o prosečnim ocenama i da individualne varijacije svakako postoje, iako nas u ovom radu zanimaju pre svega tendencije u ocenjivanju čitavih generacija. Imamo 4 istraživanja, svako sa po 12 parova prideva, pa bi sve mere raspršenja rezultata veoma otežale tekst, ali se može reći da se velika većina standardnih devijacija kreće u opsegu od 1,6 do 1,7, što za sedmostepenu skalu nije malo. Kada još bliže pogledamo raspršenja rezultata, odnosno frekvencije odgovora od 1 do 7 , tipično oko $20 \%$ ispitanika ocenjuje nacionalizam ispod teorijske nule (ocene 4), 20-30\% daje ocenu 4, dok ga većina od 50-60\% svrstava u pozitivni deo skale (od toga 10-20\%, zavisno od prideva i godine, daje ocenu 7).

Grafikon 3. Socijalizam

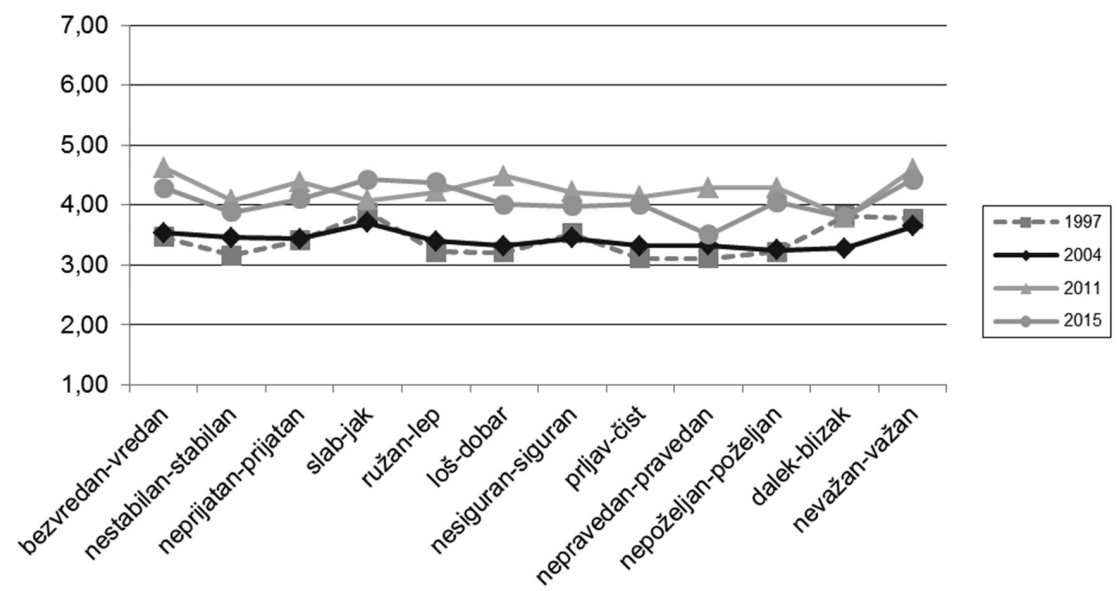


Socijalizam je termin čije ocene su ujednačene i formiraju relativno ravnu liniju. U ovih 20 godina o socijalizmu kao teorijskom pojmu i društvenom uređenju uglavnom se, u Srbiji, nisu vodile šire društvene rasprave, osim što je neretko spominjan kao manje efikasan u odnosu na liberalni (pre svega ekonomski) model. Međutim, ni jedna vlada Srbije se nije usudila da previše menja bazično socijalističke zakone i prakse poput prava na penzije, finansiranje zdravstva ili školstva, pa i niz privilegija određenim slojevima stanovništva (npr. besplatni gradski saobraćaj za sve preko 65 godina i učenike osnovnih škola u Beogradu). U periodu SFRJ te rasprave su uglavnom služile za promociju socijalizma, ali već 1960-ih je socijalizam, nesporan kao koncept i uređenje, kritikovan sa stanovišta realizacije (npr. grupa oko Praxisa), da bi 1980-ih dolazilo i do ozbiljnog osporavanja posebno među stručnjacima i političarima, no postojeći izvori generalno ukazuju da su mladi i drugi običan svet i dalje smatrali socijalizam nespornim (Vrcan i dr., 1986). Rasprave o socijalizmu su postojale i u mnogim drugim zemljama sveta kao posledica Hladnog rata i težnje tadašnjih svetskih intelektualnih elita da promovišu ili kritikuju te ideje i taj sistem. U današnje vreme, čini nam se da su te rasprave ostale društveno relevantne i snažne samo u Latinskoj Americi, i posebno su vidljive u brojnim svetskim medijima uoči izbora u zemljama od Meksika do Argentine. Narodna Republika Kina ima svoj specifičan odnos prema socijalizmu, koji je teško primenljiv na naše uslove, dok se u Evropi, posebno zapadnoj, težište ciljeva tradicionalnih socijalističkih i sociodemokratskih stranaka pomerio sa pitanja prava radnika i socijalne države, koja su preovladavala u drugoj polovini XX veka, na pitanja koja te stranke približavaju političkom centru i liberalnim idejama (tipičan je primer Novih laburista Tonija Blera u Britaniji 1990-ih, koje su sličnim promenama programa pratili i socijaldemokrati G. Šredera u Nemačkoj). Velike tradicionalne socijalističke stranke u Evropi se gotovo ili zaista gube i nestaju (PASOK, socijalisti u Francuskoj, Italiji), dok u Nemačkoj SDP beleži najnižu podršku od kraja rata. ${ }^{2}$ Pomenimo da se u poslednje vreme, i u Evropi i kod nas, pojavljuje sve više, malih po broju i uticaju, levičarskih udruženja koja eksplicitno pominju socijalizam i socijalističke ideje, u širokom spektru, od onih proisteklih iz feminističkog pokreta, preko antiglobalističkih, do marksističkih organizacija koje i danas objašnjavaju razne društvene probleme i nude rešenja zasnovana na delu Karla Marksa i tzv. klasika marksizma, ali sa čijim delovanjem nije upoznat velik broj ljudi (iako neki od njih obilno koriste prednosti tehnologije i promovišu se na društvenim mrežama i slično). Stoga bi ravna linija blizu središnje linije (linije koja ide od broja 4) mogla da ukazuje i na ne preveliku zainteresovanost za pitanja ideologija i društvenih uređenja u ovakvom uzorku. Smatramo da nije previše smela

${ }^{2} \mathrm{O}$ današnjem stanju socijalizma u Evropi više na portalu https://www.socialeurope.eu. 
pretpostavka da bi, da imamo i liniju iz 1960-ih ili 1970-ih godina, ona bila na samom vrhu ovog našeg grafikona. Međutim, primećuje se ujednačeno podizanje te linije, odnosno popravljanje odnosa prema socijalizmu u poslednjoj deceniji. Ta linija je u prva dva istraživanja išla nešto ispod teorijskog proseka (ocene su bile u proseku blago negativne), delom zbog generalnog odijuma prema socijalizmu nakon pada Berlinskog zida, a delom i zbog vodeće političke stranke u Srbiji tokom veoma teških 1990-ih godina, Socijalističke partije. Posebno za mlade ljude, koji još nisu bili završili ni srednju školu, gotovo da nije bilo drugih asocijacija na socijalizam. Taj odijum je i dalje bio prisutan 2004., nepune četiri godine nakon što je u Srbiji sa vlasti sišla stranka koja u imenu ima pojam socijalizam, i kada su kod većine građana još uvek bile prisutne nade da će, između ostalog i udaljavanjem od socijalizma i svega što on predstavlja, stvari ići na bolje. Međutim, svetska ekonomska kriza, teškoće u brzom napredovanju zemlje u željenom pravcu i gubitak poverenja u novi društveni model i "kraj istorije" (Fukujama, 1998) doveli su do ponovnog poboljšanja percepcije socijalizma u ovoj deceniji ili, preciznije rečeno, do nestajanja negativnog odnosa prema njemu. Socijalizam je najbolje ocenjen kao vredan i važan, a najveći pomak u odnosu na prethodna istraživanja je kod percepcije socijalizma kao dobrog, čistog, pravednog i poželjnog. U političkom, pa i ekonomskom ponašanju, za političare ili učesnike na tržištu (za razliku od istraživača) često nije bitno neko precizno graduiranje, nego pre relativni odnosi između potencijalnih alternativa. Bitno je za koga ćemo glasati, a manje bitno da li smo za tu stranku ili kandidata glasali jer je "manje zlo" ili naš jedini izbor, ili najbolji izbor između više dobrih opcija. U komercijalnim istraživanjima ultimativni prediktor jeste da li ćemo neki proizvod kupiti ili ne. O tome govore i teorije razložne akcije (Fishbein i Ajzen, 1975), odnosno planiranog ponašanja (Ajzen, 1985), koje ukazuju da na naše ponašanje ne utiče samo naš odnos (stav) prema objektu, već i socijalne norme, kao i opažena bihejvioralna kontrola. I ovo sve ne utiče direktno na ponašanje, nego samo na nameru, a na ponašanje pored namere utiču i brojni spoljašnji i nekontrolabilni faktori. U tom smislu ovde je vrlo važno da iako su promene u percepciji socijalizma relativno male, preskočena je neutralna tačka, tj. generalno govoreći socijalizam je umesto kao blago negativan počeo biti percipiran kao blago pozitivan. To onda nije promena koja se ogleda samo u jednoj dimenziji prikazanoj na grafikonu, već promena i u direkciji odnosa, koju bismo mogli uporediti sa tenisom gde loptica kad pada na jednu ili drugu stranu terena, mora da pređe ne samo 10 ili $20 \mathrm{~cm}$ levo ili desno, nego i da preskoči mrežicu. Stoga je značaj i minimalnih promena u direkciji stava nekad mnogo veći nego relativno veća promena "na jednoj strani”, unutar iste valence. 
Grafikon 4. Mir

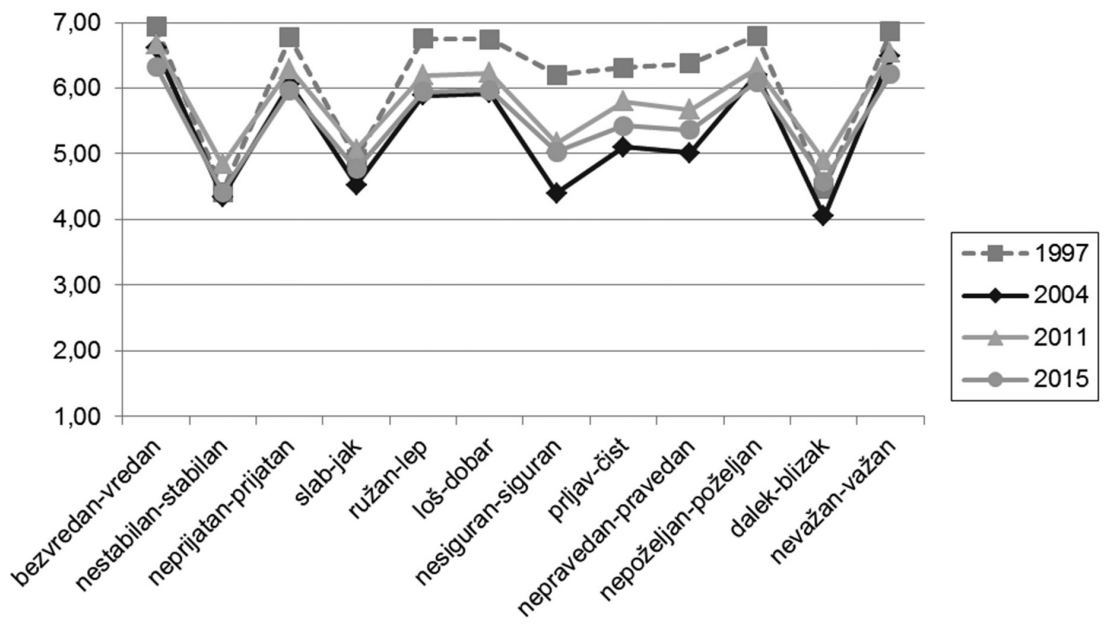

Pojam mir je ocenjen prilično pozitivno, mada neujednačeno po datim pridevima. Na nekim pridevima ocenjen je izrazito pozitivno, gotovo maksimalno, npr. vredan, važan, poželjan, prijatan, dok po drugim dimenzijama jedva prelazi u pozitivni deo: nije toliko blizak, ni jak, stabilan niti siguran. Odmah se vidi da je pojam mir najpozitivnije ocenjen 1997. godine, neposredno po završetku višegodišnjeg rata u Bosni i Hercegovini i Hrvatskoj, dok je 2004., nakon bombardovanja same Srbije ocenjen nešto manje pozitivno. Očigledno je da je generaciji koja je pohađala deo osnovne i srednje škole u vreme ratnih sukoba mir bio nešto nedostižno i željeno, i zato je mir nosio snažnu pozitivnu konotaciju. U prilog tome govore čak i pridevi po kojima je mir naizgled slabije ocenjen: ne toliko stabilan, blizak i siguran. Ukoliko je nešto izuzetno vredno, prijatno, poželjno i važno, a uz to nije toliko stabilno i sigurno, to su razlozi da se još više i skrupuloznije čuva i održava. Ovi nalazi se dakle mogu tumačiti preko geštaltističkih principa formiranja impresije, po kojima jedna ista reč, odnosno isti atribut u različitom kontekstu ima različitu ulogu i značenje (Asch, po Havelka, 1992). Naravno, kada nismo direktno ugroženi, kao $\mathrm{u}$ tri studije u ovom veku, ne obraćamo maksimalnu pozornost na određenu stvar, te mir nije maksimalno pozitivan, ali i dalje to jeste u veoma velikom stepenu. Pomenimo da smo u prvim studijama koristili i pojam sloboda, međutim, taj pojam je davao gotovo iste rezultate kao mir, mada smo pretpostavljali da bi moglo biti razlika jer je mir stanje bez rata, u bilo kojim okolnostima, čak ako idemo do ekstrema i u okupaciji, a sloboda je potpuno pozitivan mir. No, kako je već reč mir imala izrazito pozitivne konotacije, nije bilo mesta za još više, očekivane, konotacije pojma sloboda, nego je rezultat bio gotovo izjednačen, pa je pojam sloboda izostavljen iz da- 
ljih analiza. Ovo posebno stoga što su definicije mira ispitanika bile da je to stanje bez rata, kad se ne puca i slično, a da niko nije razumeo mir kao unutrašnji spokoj.

Grafikon 5. Demokratija

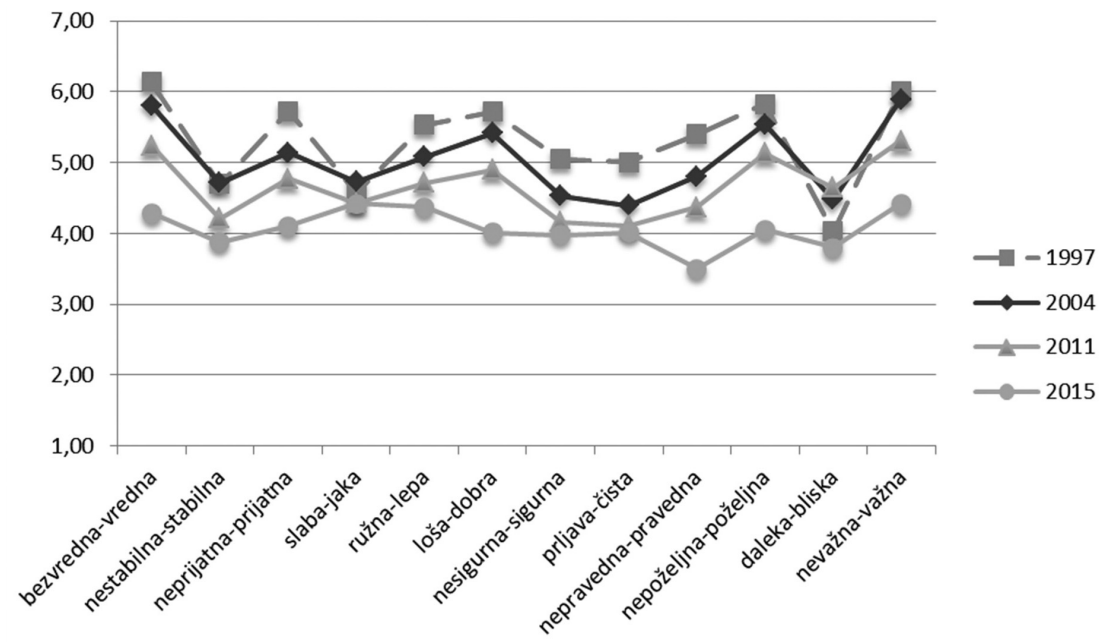

Demokratija je pojam za koji se očekuje da bude visoko pozitivno ocenjen, za njega se vezuju velike ideje i poduhvati, i velika odricanja da bi se do nje stiglo. Tokom istorije borba za demokratiju se može porediti sa borbom za slobodu, dakle možemo je svrstati u najviše društvene ideale. Ali, kako su stvari obično komplikovane, dešavalo se da se među stanovništvom Indije pored ponosa zbog sopstvene demokratije nađe i zavist prema Kini zbog većeg ekonomskog rasta i boljeg standarda, sa indicijama da bi donekle menjali tu svoju veliku i očitu komparativnu prednost za malo više materijalnih dobara. Čak i posle Drugog svetskog rata u FNRJ, uprkos ukidanju višestranačkog sistema kao jednog od osnovnih činioca demokratije, taj pojam je promovisan i istican, te je imao veoma pozitivno značenje. Narodna demokratija, kako se tada neretko govorilo, zasnivala se na njenoj osnovnoj definiciji da je to Demos Kratein iliti vlast naroda, odnosno većine nad manjinom (radničke klase nad buržoazijom). Međutim, demokratija je i primer kako isti pojam može biti određen različito u različitim istorijskim epohama, te je onda bilo moguće dobiti visoko pozitivno konotativno značenje ovog pojma u isto vreme u posleratnoj Titovoj Jugoslaviji i u Britaniji ili SAD. Danas je situacija sa ovim pojmom još složenija, jer se u svetu sve manje pod tim pojmom smatra vladavina većine (koja je često određena negativnim pojmom populizam), već se pre pod demokratijom podrazumeva sistem liberalnih vrednosti koje najčešće uključuju upravo ono suprotno većini, a to su prava manjina. No i ova novina je, bar u Srbiji postala šire poznata tek poslednjih godi- 
na pa je mogla da utiče samo na poslednju, ili poslednje dve studije. Tokom 1990-ih u javnosti je bilo veoma široko rasprostranjeno mišljenje da je vlast nedemokratska te da je to povezano i sa lošijim životnim standardom i ugledom zemlje u svetu. Sa druge strane, značajan deo starije populacije, koji ovde nije ispitivan, povezivao je demokratiju sa pojavom višestranačkog sistema, što je sasvim prikladno, ali i sa izuzetno negativnim događajima koji su se poklopili sa završetkom jednostranačkog sistema u Jugoslaviji, sa raspadom zemlje i ratovima.

Međutim, naši ispitanici nemaju očekivano visoko viđenje demokratije, nego su u mnogim dimenzijama veoma sumnjičavi prema ovom pojmu. Demokratija jeste uglavnom iznad neutralne linije sa brojem 4, ali i jasno i vidljivo opada njena pozitivnost. Što je društvo objektivno postizalo veći stepen demokratičnosti (slobodni izbori, veća sloboda medija), demokratija je sve manje pozitivno ocenjivana. Godine 1997. demokratija je viđena kao mnogo prijatnija, pravednija, čistija i vrednija nego sedam godina kasnije, a nakon sledećih sedam godina te procene su dalje degradirale, da bi 2015. demokratija u značajnoj meri izgubila pozitivnu konotaciju. Ocena demokratije kao nečeg vrednog je u prvoj studiji prelazila ocenu 6. Dakle bila je viđena kao ekstremno vredna. Postoji niz indicija iz ispitivanja slobodnih definicija ovih pojmova da je demokratija pre viđena u instrumentalnom smislu, kao mogućnost da se ostvari bolji život, pre svega u materijalnom smislu, a mnogo manje u smislu viših potreba (u Maslovljevom smislu) poput slobode. Promene 2000. godine nisu donele svima i onoliko očekivanih poboljšanja u životima koliko su očekivali, između ostalog i zato što su aspiracija i očekivanja bili veoma visoki. Iako je došlo do određenih značajnih poboljšanja, od statusa zemlje u svetu pa do povećanja prosečnih plata, javila se i jedna velika grupa tzv. tranzicionih gubitnika, među kojima ima i roditelja naših ispitanika. Neki od njih su izgubili posao, ali čak i oni kojima su primanja u apsolutnim iznosima porasla mogli su da dožive relativnu deprivaciju, odnosno da budu u lošijem položaju u odnosu na sopstveno okruženje u odnosu na 1990-e kada je veći broj ljudi bio veoma siromašan. Ljudsko zadovoljstvo životom mnogo više zavisi od tih relativnih poređenja nego od nekih apsolutnih cifara, te su tranzicioni gubitnici i članovi njihovih porodica za svoj percipirano lošiji položaj mogli da okrive i demokratiju. Pored ekonomskih pojavili su se i brojni politički izazovi koje je deo populacije smatrao nepravičnim, prvo u pogledu pritisaka međunarodne zajednice $u$ vezi sa Tribunalom $u$ Hagu, a potom u pogledu statusa Crne Gore i u mnogo većem stepenu Kosova. Desne političke ideologije su to povezivale direktno sa demokratijom, čije viđenje postaje sve manje pozitivno, pa čak 2015. na čitavom uzorku biva viđena pre kao nepravedna nego kao pravedna (ispod 4). Potvrdu ovih rezultata, na osnovu istraživanja iz tri ciklusa Svetske studije vrednosti, rađenu drugom metodologijom, ali na reprezentativnom uzorku, pruža Pavlović (2010), koji pokazuje nagli rast prihvatanja demokratske orijentacije u Srbiji 2001. u odnosu na 1996., a potom i, takođe nagli, pad 2006. 
Grafikon 6. Vođa

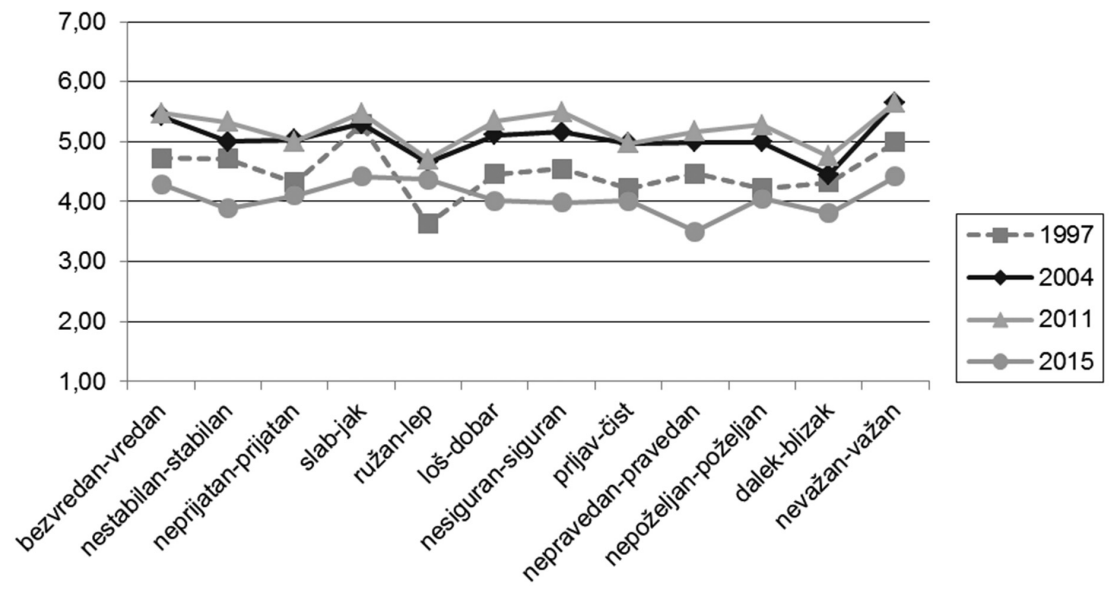

Mnoga istraživanja u Jugoslaviji i Srbiji su pokazala visok stepen autoritarnosti, koja uključuje i težnju za vođom, u ispitivanim uzorcima (Kuzmanović, 2010) pa time verovatno i u populaciji u celini. Međutim, lideri i liderstvo u određenim okolnostima imaju i pozitivno značenje, ne misli se uvek na nekog diktatora, nego se posebno u novije vreme ističe da lider, predsednik, vođa "treba da preuzme inicijativu”, "da pokaže liderstvo", "da preuzme odgovornost". I naši rezultati potvrđuju da je pojam lidera ili vođe nešto što se procenjuje u pozitivnom delu skale. Vođa je uvek bio nešto što se vidi kao važno i jako, međutim, ovde ima najviše vremenskih uspona i padova kroz vreme, gotovo na svakom pridevskom paru. Ima autora koji smatraju da je nekritičko veličanje ideje vođe nasuprot demokratskim institucijama jedno od suštinskih karakteristika autoritarnosti. To ne znači da svi autoritarci moraju veličati postojeće vođe. Štaviše, prema njima mogu biti i vrlo kritični, ali su ipak opsednuti idejom da nam treba, jak, energičan, strog vođa, po mogućnosti i pravedan, i da nam on može rešiti većinu društvenih problema. Govori se i o "vapaju” za takvim vođom (npr. Kuzmanović, 2010). Verovatno su i ovog puta neki naši ispitanici u pridavanju konotativnog značenja pojmu "vođe” mislili na nekog postojećeg, a drugi na tog za njih "idealnog". Ocene su bile nešto niže u prvom istraživanju jer su ispitanici očigledno imali u vidu tadašnjeg predsednika Republike koji nije bio popularan, barem među mlađim stanovnicima (npr. Popadić, 1993: 121). Još su niže u poslednjem istraživanju, ali moramo biti skeptični prema pretpostavci da je razlog isti. Naime tadašnji premijer, a sadašnji predsednik je tada bio na vlasti svega par godina, i nije bio medijski eksponiran i javno kritikovan kao u kasnijem periodu. Mogli bismo potražiti obrazloženje za ovakav rezultat i u opadanju važnosti klasičnih autoriteta u mlađim generacijama, kao jednoj globalnoj tendenciji: zbog načina 
života, mnogo veće dostupnosti mogućnosti i informacija, zahvaljujući pre svega revolucionarnom razvoju tehnologije. No pre svega, potvrdu da mladi nemaju ni malo poverenja u vođe i da se oni nalaze na dnu liste poverenja nalazimo i u najnovijim istraživanjima u Srbiji i regionu (Popadić i sar., 2019: 24).

Grafikon 7. Sadašnjost

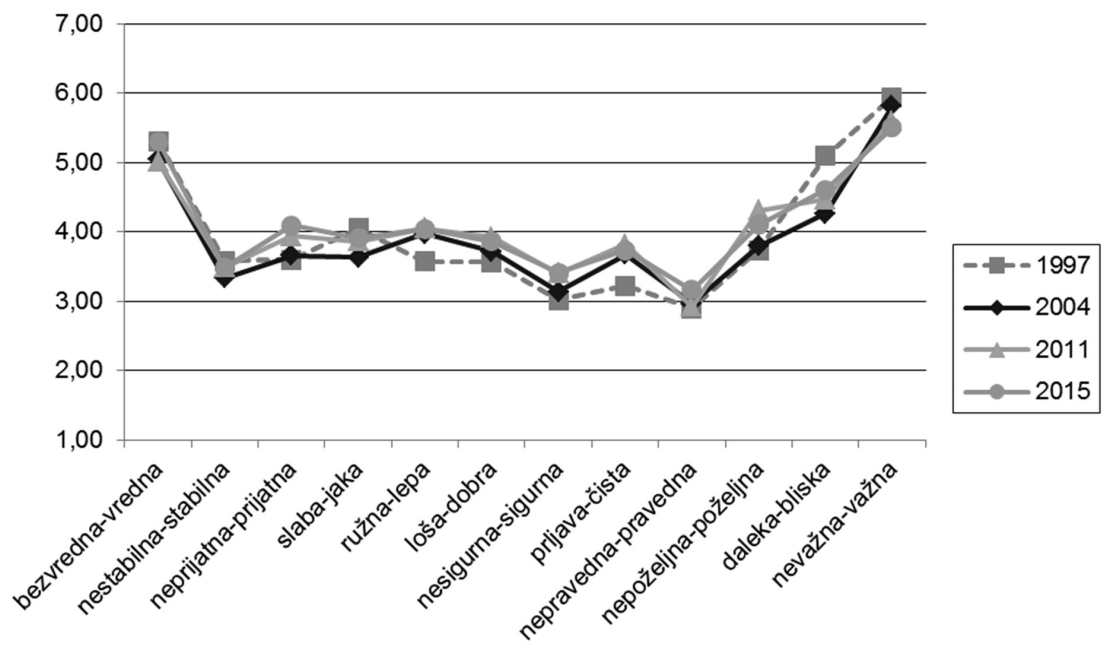

Mladi ljudi su pojam sadašnjosti ocenjivali podjednako u ova četiri vremenska razdoblja. Mladost je buran formativni period, period uspona, razvoja, traženja i zauzimanja svog mesta u svetu, te po mnogima možda i (bar subjektivno i u tom periodu percipirano) najvažniji period života. Zato je zanimljivo da ga mladi u Srbiji, koji se, kako smo videli, ne slažu u mnogim društvenim značenjima, u periodu od dve decenije vide potpuno istovetno. Međutim, ovaj pojam je procenjivan veoma različito po različitim dimenzijama. Sadašnjost je izuzetno važna za mlade osobe, tu dostiže ocenu 6. Ona je bliska i vredna. Ali nije toliko vredna koliko je važna. Ovo je prvi i najblaži indikator nezadovoljstva mladih. Ono što je više zabrinjavajuće jeste da se ovde okončavaju atributi na kojima je sadašnjost viđena pozitivno. Ona je po poželjnosti i prijatnosti na graničnoj liniji 4, što bi, na žalost, moglo da znači da bi idealno trebalo da bude bolja, a da je u realnosti ne tako poželjna i prijatna. Sadašnjost se, dalje, vidi i kao nepravedna i nesigurna, pa i prljava, loša i nestabilna. Ova diskrepancija između važnosti i potonjih osobina ukazuje na očigledno nezadovoljstvo mladih zbog toga što ne dobijaju dovoljno u onome što ocenjuju kao veoma važno. Iako sadašnjost nije striktno politički pojam, ove rezultate smatramo izuzetno (i) politički relevantnim i znakom da je potreban ozbiljan rad na formira- 
nju društva u kome nove generacije neće stupati u odraslo doba već razočarane $u$ ono što ih čeka. Potvrdu ozbiljnih strepnji sa dalekosežnim negativnim posledicama nalazimo u viđenju pojma budućnost.

Grafikon 8. Budućnost

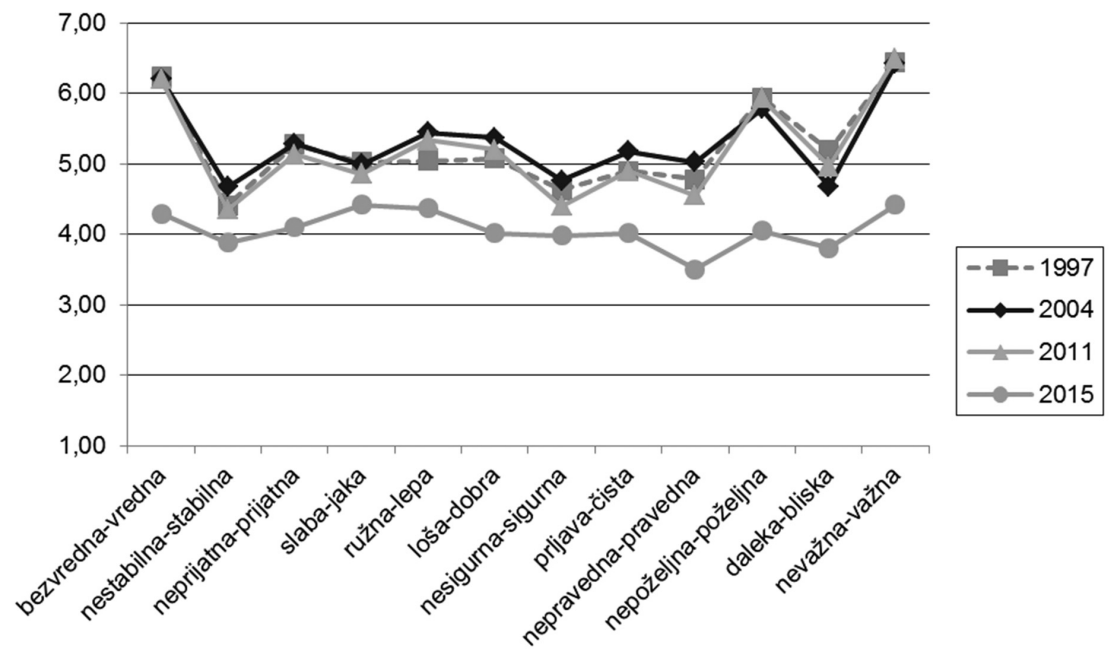

Budućnost pripada mladima i to nije samo parola. Svetla budućnost je bila glavna parola tokom nekoliko decenija u SFRJ, dok su ideali svetle budućnosti, barem po mišljenju odraslih, bili prisutni i drugde u svetu. Poznata je cinična pesma "Budućnost je tako svetla da moram da nosim tamne naočare", koju su izvodili i najveći svetski bendovi kao Dire Straits i Status Quo. Mirjana Ule (1986: 111) je utvrdila da među jugoslovenskom omladinom $83 \%$ veruje da će njihova lična budućnost biti mnogo bolja ili bolja od sadašnjosti, dok za budućnost društva to misli $63 \%$ mladih.

I pojam budućnosti mladi su ocenjivali identično u prve tri studije, mada ne $\mathrm{i}$ po raznim dimenzijama. Za njih je budućnost bila izuzetno važna, vredna i poželjna; međutim, ne vide je kao stabilnu i sigurnu, a ne izgleda im ni toliko bliska. To su bili rezultati nad kojima bi se trebalo zamisliti. Međutim, ono što je dobijeno u poslednjoj studiji 2015. govori o veoma ozbiljnim, već postojećim, posledicama koje se više ne mogu prevenirati, nego se moraju sanirati. Dakle nezadovoljstvo sadašnjošću je jedna stvar, i pozitivna reakcija na sadašnje nezadovoljstvo jeste trud da se ona promeni i da se popravi, za šta je potrebno videti pozitivni cilj, svetlo "na kraju tunela". Rezultati iz 2015. su uznemirujući i govore o apatiji i besperspektivnosti, o odgovorima onih kojima su mnoge nade na ivici propadanja i koji se polako 
prepuštaju entropiji. Budućnost jedva prelazi, u proseku, neutralnu crtu kao važna i vredna (i tu je za čitava dva poena manja od prethodnih generacija), dok je čak ispod neutralne crte i viđena je u proseku kao nestabilna i nepravedna. Ona nije mladima od 19 godina više lepa, dobra i poželjna nego što je ružna, loša i nepoželjna! I Popadić i saradnici (2019: 22) nalaze da jedna trećina ispitanika smatra da će biti bolje, 23 odsto smatra da će biti isto, a 21 odsto očekuje da će biti gore nego što je sada. Oni još tvrde da među mladima po ovom pitanju nema razlika prema polu, uzrastu ili društveno-ekonomskom položaju. Neke od posledica, ako ne negativnog, ono bar ni pozitivnog gledanja u budućnost su vidljive i kroz ogromni stepen emigracije posebno mladih, ne samo iz Srbije, nego i susednih država, pa i onih koje pripadaju EU: Bugarska, Hrvatska. Autori ove studije su posumnjali u validnost podataka, u nehajno popunjavanje upitnika i na svaki drugi način tražili razlog da ne prihvate ove rezultate. Međutim, ovo je bilo jedinstveno, kompatibilno istraživanje na oko 200 ljudi i potpuno je nemoguće da samo jedan deo upitnika toliki broj ljudi ne popuni na isti način kao ostale delove. Izgleda da relativno noviji domaći filmovi u velikom broju (ne računajući one o direktnoj zaostavštini ratova) nisu samo umetnička preterivanja o besperspektivnosti, poput filmova: "Beli, beli svet", "Pored mene", "Čekaj me ja sigurno neću doći”, "Tilva Roš”, "Klip”, "Đavolja varoš”, "Hadersfild"... Toliki broj filmova o potpunoj besperspektivnosti mora da odražava donekle i objektivnu realnost.

Grafikon 9. Levica

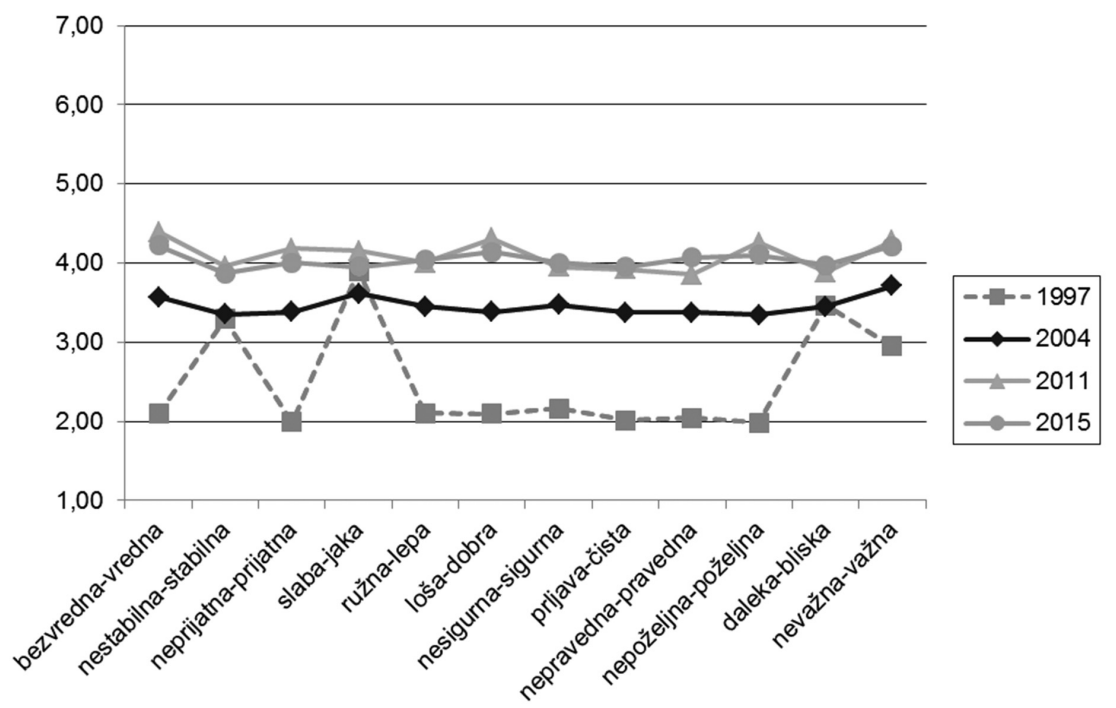


Pojam političke levice je među najzanimljivijim, i onim gde su se desile najveće promene. Tokom 1990-ih pojam levice je bio vezivan za jednu, prilično omraženu stranku, koja je reč levica imala u nazivu i koja je imala velik uticaj bez zasnovanosti u biračkom telu. Zato je levica percipirana kao jaka, pa i bliska i stabilna, ali veoma negativno po svim evaluativnim dimenzijama (nepoželjna, prljava, neprijatna i sl.). Po većini pridevskih parova ispitanici su u $60 \%$ slučajeva davali ocenu 1 , a tamo gde su proseci nešto viši, postoji velika standardna devijacija, do 2,4, što znači da su neki ispitanici levicu uniformno ocenjivali sa najnižom ocenom, a neki drugi u slučajevima jaka, bliska i stabilna davali i visoke pozitivne ocene. U drugom istraživanju (u međuvremenu je ta stranka prestala da postoji) levica je i dalje percipirana negativno, ali tek nešto ispod teorijskog proseka. U poslednja dva istraživanja levica se, u proseku, procenjuje veoma ravnomerno i neutralno (25-40\% daju ocenu 4, a standardne devijacije su tipične za čitavo istraživanje, između 1 i 1,5). Jedan razlog za to možemo potražiti u slaboj zainteresovanosti mladih za politiku, te ocene oko neutralne tačke mogu da znače i "ne znam" ili "nemam stav".

Grafikon 10. Desnica

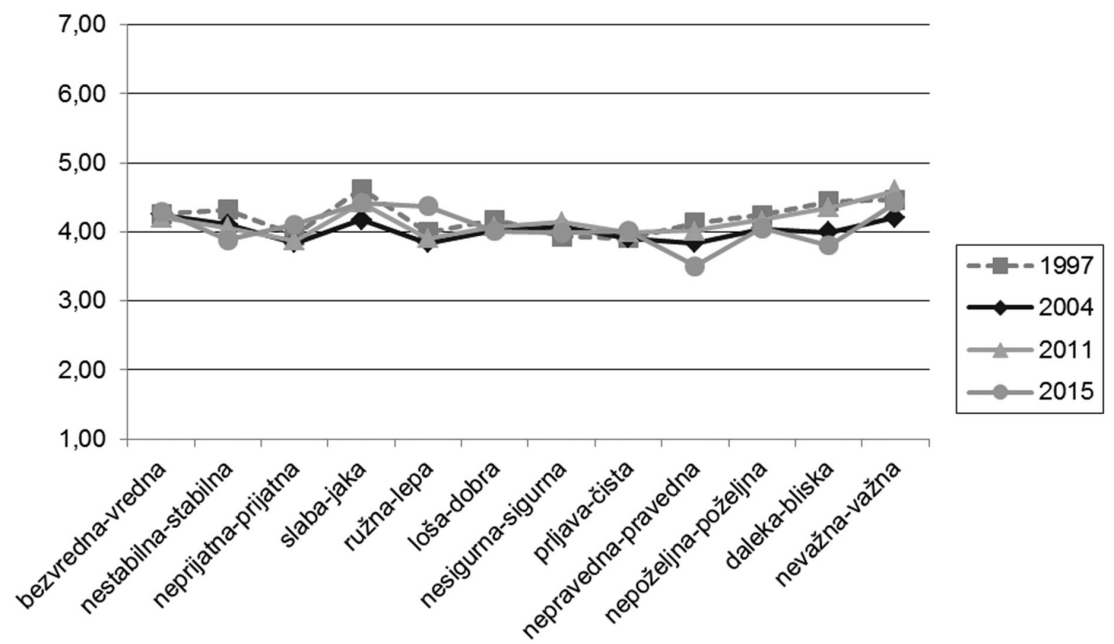

Konačno, pojam političke desnice je najneutralnije procenjen pojam, u sva tri istraživanja po svim dimenzijama je ocenjen gotovo potpuno neutralno. Ovde još više do izražaja dolazi to da je reč o direktnijem političkom konceptu (kao i levica), koji nema toliko uticaja na život većeg broja ljudi kao pojmovi poput nacije ili demokratije, te su mnogi nezainteresovani i bez izraženog stava. Ovome u prilog idu naši rezultati gde standardna devijacija, u odnosu na ostale pojmove, nije tako 
velika i uglavnom tek prelazi 1. Jasniji podatak opet može biti distribucija rezultata: desnicu je neutralno, sa 4 ocenilo $40-50 \%$ ispitanika (zavisno od para prideva), a još po oko $10 \%$ desnicu ocenjuje sa 3 ili 5 . Tako da manje od trećine ispitanika ima polarizovan i jasno pozitivan ili negativan odnos prema pojmu desnice izražen kroz ocene 1, 2, 6 i 7. Čini se da se levica u javnom diskursu ipak donekle pominje kao neka vrsta socijalne pravde, ili kroz javne aktivnosti popularnih mislilaca (Horvat, Žižek, Muhika), dok je desnica prilično nejasna ispitanicima, odnosno čini se da je često nepostojanje minimalnog znanja o denotativnom značenju ovoga pojma.

\section{Zaključna razmatranja}

Stanje u društvu i dominantne društvene vrednosti možemo utvrditi na različite direktne i indirektne načine. Direktno možemo posmatrati ili pitati ljude u anketnim istraživanjima ako je u centru pažnje sadašnji period. Indirektne metode možemo koristiti i za ispitivanje prošlosti. Koje institucije su postojale i gde je bio centar moći i odlučivanja, koliko je napredovala nauka i umetnost i šta su umetnička dela slala kao osnovnu poruku, neki su od načina na koje politikolozi, istoričari i drugi društveni naučnici procenjuju dominantne vrednosti u jednom društvu. U ovom istraživanju pokušali smo da sa socijalnopsihološke tačke gledišta, koristeći jednu relativno retko korišćenu tehniku, utvrdimo promene u srpskom društvu, barem kod mladih, u jednom dinamičnom, ne potpuno revolucionarnom, ali svakako ne stabilnom periodu njegovog razvoja, u poslednjih dvadesetak godina. Tehnika semantičkog diferencijala nam je pružila mogućnost da izmerimo konotativno, odnosno emocionalno obojeno značenje koje se pridaje nekim relevantnim rečima u društveno-političkom diskursu. Osnovna pretpostavka jeste da na tu obojenost utiče društveni okvir te da se sa njegovom promenom drugačije doživljavaju i određene reči.

Pošto je svaka reč procenjivana na čak po 12 pridevskih parova, to je omogućilo suptilniju analizu, a ne samo opšti odnos prema pojmovima. Nacija, kao pojam, je ocenjena kao važna, vredna, lepa i dobra, što bi bilo u skladu sa teorijom socijalnog identiteta; mada nije specifikovano da li se misli na sopstvenu naciju, ipak je bilo za očekivati da će to biti referentna tačka za većinu ispitanika. Nakon promena 2000. kao i u poslednjoj studiji nacija je ocenjena manje pravednom, poželjnom, pa i važnom nego u prvom i trećem istraživanju. Nacionalizam je ocenjen blago pozitivno i nije bilo velikih promena u njegovoj percepciji u ovim godinama. Za razliku od njega, socijalizam je ocenjen ujednačeno po atributima, mada je ta ujednačena linija u prva dva istraživanja išla nešto ispod, a u potonja dva nešto iznad proseka. Mir je ocenjen veoma pozitivno, pa i oni slabije ocenjeni atributi, ne tako jak i siguran, u celini pojačavaju sliku mira kao nečeg vrednog što mora da se čuva i ne uzima zdravo za gotovo. Demokratija se u percepciji mladih vidi sve manje pozitivno kroz vreme, te to može da bude signal da se na tom polju treba više raditi ako 
želimo da ona ostane pozitivna društvena vrednost. Zanimljivo je, mada donekle paradoksalno da dok se sve manje veruje u demokratiju, takođe se sve manje veruje i u vođu. Uže političke odrednice levica i desnica su (osim levice 1997. jako loše) ocenjene veoma neutralno, što može da ukazuje na nezainteresovanost mladih za direktnija politička pitanja. Konačno, vremenske odrednice sadašnjost i budućnost ukazuju da mladi u svim generacijama vide diskrepanciju između željene važnosti ovih pojmova i njihove krhkosti i, kako oni smatraju, nepravednosti. Posebno je zapanjujući rezultat iz poslednje studije gde mladima budućnost uopšte više nije pozitivna.

Želeli smo da pokažemo da se društvena klima, odnosno doživljaj dominantnih vrednosti, može objasniti i sa psihološkog, pa i psiho-lingvističkog stanovišta. Na konotativno značenje, kako je već istaknuto, utiče i opšta klima u društvu, ali i individualni faktori poput porodičnog statusa, kao i konkretni događaji bilo društveni (proglašavanje nezavisnosti Kosova, ulazak ili priprema za Evropsku uniju) ili lični (promena radnog statusa, pristupanje političkoj organizaciji i slično). Važna je i percepcija stanja u društvu i pravca razvoja: ide li društvo u dobrom ili u lošem pravcu. Tako da svaki pojedinac ima svoje konotativno značenje svake reči: neki politički soficistiraniji više na osnovu argumenata, a drugi više na osnovu impresije i drugih spoljnih obeležja. Na mlade ljude značajno deluje i porodica, ne nužno namernim ubeđivanjem, nego često i nekom vrstom učenja po modelu (uz narative "sad je najgore", "sad je odlično, ne znate vi šta je život i šta može da nas zadesi”). Zanimljive su i očite razlike između tzv. tranzicijskih dobitnika i gubitnika (operacionalizovane kroz pitanje da li ti i tvoja porodica živite bolje ili lošije danas u odnosu na period od pre pet godina). Oni koji žive lošije su recimo skeptičniji prema demokratiji (gotovo sva poređenja između te dve grupe daju značajan t-test). Postoji i uloga vršnjaka, kao i uloga društvenih mreža, na primer u Srbiji se na Twitteru vode svakodnevne najžešće ideološke borbe.

Očigledno je da na sistem vrednosti ili društvenu klimu utiču brojni akteri, koji svi imaju veći ili manji uticaj na određene delove populacije (političke stranke, neformalne organizacije, socijalno poreklo i status) ili čitavu populaciju (npr. kroz medije, školski sistem). Konačni prosečni skorovi koje smo mi prikazali bivaju rezultanta svih tih uticaja, i nekada mogu da budu i veštački proseci koje čine oni koji su mnogo viši i mnogo niži na merenim dimenzijama. Međutim, ovo je pre svega empirijski rad koji nudi sliku nekoliko generacija i promene u četiri generacije tokom dve decenije, dok kolegama drugih specijalnosti ostavljamo da ponude rešenja za uočene probleme ili za poboljšanje zatečene situacije. 


\section{LITERATURA}

Ajzen, Icek. 1985. From intention to action: A theory of planned behavior, u: Kuhl, J., Beckmann, J. (ur.): Action control: From cognition to behavior. Springer-Verlag. Berlin, Heidelberg, New York: 11-39.

Bačević, Ljiljana i dr., ur. 1991. Jugoslavija na kriznoj prekretnici. Konzorcijum Instituta društvenih nauka u Jugoslaviji. Beograd.

Bar-Tal, Daniel. 1997. The monopolization of patriotism, u: Bar-Tal, D., Staub, E. (ur.): Patriotism in the life of individuals and nations. Nelson-Hall Publishers. Chicago: 246-270.

Bar-Tal, Daniel. 2000. Shared Beliefs in a Society: Social Psychological Analysis. SAGE. London.

Biro, Mikloš; Mihić, Vladimir; Milin, Petar i Logar-Đurić, Svetlana. 2002. Da li su društveno-političke promene u Srbiji promenile nivo autoritarnosti i etnocentrizma građana? Psihologija, (35), 1-2: 37-47.

Blanuša, Nebojša i Šiber, Ivan. 2011. Nade i strahovi mladih prema Europskoj Uniji, u: Šiber, I. (ur.): Hrvatska i Europa - strahovi i nade. Fakultet političkih znanosti. Zagreb: 86-119.

Brinton, J. E. 1961. Deriving on Attitude Scale from Semantic Differential Data. Public Opinion Quarterly, 25: 289-295.

Fishbein, M. i Ajzen, I. 1975. Belief, attitude, intention and behavior: an introduction to theory and research. Addison-Wesley Publishing Company, Inc. Reading, Massachusetts.

Flere, Sergej. 1986. Odnos mladih prema etnosu, u: Vrcan i dr. (ur.): Položaj, svest i ponašanje mlade generacije Jugoslavije. IDIS i CIDID. Zagreb i Beograd.

From, Erih. 2016 [1941]. Bekstvo od slobode. Nova knjiga. Podgorica.

Fukujama, Frensis. 1998. Kraj istorije i poslednji čovek. CID. Podgorica.

Guetzkow, Harold S. 1955. Multiple loyalties. Princeton University. Princeton, N.J.

Kuzmanović, Bora i Petrović, Nebojša. 2005. Promene konotativnog značenja politički relevantnih pojmova kod beogradskih srednjoškolaca. Psihologija, (38), 4: 423444.

Harari, Juval Noa. 2019. 21 lekcija za 21. vek. Laguna. Beograd.

Havelka, Nenad. 1992. Socijalna percepcija. Zavod za udžbenike i nastavna sredstva. Beograd.

Havelka, Nenad; Kuzmanović, Bora i Popadić, Dragan. 1995. Metode i tehnike socijalnopsiholoških istraživanja. Društvo psihologa Srbije. Beograd.

Himmelfarb, Samuel. 1993. The measurement of attitudes, u: Eagtly, A. H., Chaiken, S. (ur.): The Psychology of Attitudes. Harcourt Brace Jovanovich. Fort Worth, TX: 23-88. 
Kuzmanović, Bora. 2010. Autoritarnost - vapaj za jakim i pouzdanim vođama i disciplinom, u: Mihailović, Srećko i drugi (ur.): Kako građani Srbije vide tranziciju: istraživanje javnog mnenja o tranziciji. Friedrich Ebert Stiftung. Beograd: 87-103.

Lazaroski, Jakov. 1994. Nacionalnata privrzenost i odnosot sprami drugi narodi. NIO Studentski zbor. Skopje.

Likert, Rensis. 1932. A Technique for the Measurement of Attitudes. Archives of Psychology, 140: 5-55.

Milošević-Đorđević, Jasna. 2007. Primordijalističko značenje nacionalnog identiteta u Srbiji. Psihologija, (40), 3: 385-397.

Osgood, Charles E. 1952. The Nature and Measurement of Meaning. Psychological Bulletin, 49: 197-237.

Osgood, Charles E. 1964. Semantic differential technique in the comparative study of cultures. American Anthropologist, (66), 3: 171-200.

Osgood, Charles E.; May, William H. i Miron, Murray S. 1975. Cross-Cultural Universals of Affective Meaning. University of Illinois Press. Urbana, IL.

Osgood, Charles E.; Suci, George J. i Tannenbaum, Percy H. 1957. The measurement of meaning. University of Illinois Press. Urbana, IL.

Pavlović, Zoran. 2010. Prihvatanje demokratije i demokratske orijentacije u Srbiji u kontekstu društvenih promena. Psihološka istraživanja, (13), 1: 35-58.

Petrenko, V. F. 1993. Meaning as a unit of conscience. Journal of Russian and East-European Psychology, 2: 3-29.

Popadić, Dragan. 1993. Stranačka opredeljenja studenata, u: Kuzmanović, B. i sar. (ur.): Studentski protest 1992. Institut za psihologiju. Beograd: 111-131.

Popadić, Dragan; Pavlović, Zoran i Mihajlović, Srećko. 2019. Mladi u Srbiji 2018/19. FES. Beograd.

Petrović, Nebojša i Kuzmanović, Bora. 1998. Konotativno značenje politički relevantnih pojmova kod učenika srednjih škola. Psihologija, (31), 4: 365-384.

Rot, Nikola i Havelka, Nenad. 1973. Nacionalna vezanost $i$ vrednosti kod srednjoškolske omladine. Institut za psihologiju i Institut društvenih nauka. Beograd.

Snider, James G. i Osgood, Charles E. 1969. Semantic Differential Technique: A Sourcebook. Aldine. Chicago.

Tajfel, Henry i Turner, John C. 1979. An integrative theory of intergroup conflict, u: Austin, W. G., Worchel, S. (ur.): The social psychology of intergroup relations. Brooks/ Cole. Monterey, CA: 33-47.

Tannenbaum, Percy H. 1956. Initial Attitude toward Source and Concept as Factors in Attitude Change through Communication. Public Opinion Quarterly, 20: 413-425.

Ule, Mirjana. 1986. Odnos omladine prema mladosti, odraslosti i budućnosti, u: Vrcan i dr. (ur.): Položaj, svest i ponašanje mlade generacije Jugoslavije. IDIS i CIDID. Zagreb i Beograd. 
Vrcan, Srđan; Aleksić, Jordan; Dunđerović, Ratko; Flere, Sergej; Ilišin, Vlasta; Mihajlović, Srećko; Obradović, Vladimir; Radin, Furio i Ule, Mirjana, ur. 1986. Položaj, svest i ponašanje mlade generacije Jugoslavije. IDIS i CIDID. Zagreb i Beograd.

Nebojša Petrović, Bora Kuzmanović

THE CONNOTATIVE MEANING OF SOCIALLY

AND POLITICALLY RELEVANT CONCEPTS

AS AN INDICATOR OF SOCIAL CLIMATE

- A LONGITUDINAL STUDY IN SERBIA

\begin{abstract}
Summary
This paper is a comparative study composed of four studies conducted between 1997 and 2015. The authors examine the connotative meaning of politically relevant concepts in 18-19 years old students from various types of secondary schools. The connotative meaning is an additional, emotionally colored meaning of words, and this coloration originates from the social environment and the spirit of the times. Therefore, with the changes of this meaning it is possible to follow the changes of dominant social values and social climate. The sample consisted of a total of 750 students assessing the following concepts, at four time points (sub-samples at these points were balanced in terms of socio-demographic characteristics): nation, nationalism, socialism, leader, democracy, peace, left, right, present and future. Each of the concepts is examined by Ozgud's scale of semantic differential, through 12 opposing pairs of adjectives like bad - good or worthless - worthy. The results showed considerable variation in both: 12 adjective pairs on each single concept at a single point in time - giving a more subtle profile of meaning than in case of a general assessment of the concepts - and over time. The variations over the years give indications of a change in social climate and values, at least in the generation of young people, in these turbulent two decades in Serbia.
\end{abstract}

Keywords: Connotative Meaning of Concepts, Concepts, Youth, Society, Social Climate Change

Nebojša Petrović je redovni profesor socijalne psihologije na Filozofskom fakultetu Univerziteta u Beogradu.

Bora Kuzmanović je redovni profesor socijalne psihologije u mirovini na Filozofskom fakultetu Univerziteta u Beogradu.

Kontakti:

Nebojša Petrović, Filozofski fakultet, Čika Ljubina 18-20, 11000 Beograd, Srbija. E-mail: npetrovi@f.bg.ac.rs

Bora Kuzmanović, Pančićeva 12, 11000 Beograd, Srbija. E-mail: borakuzmanovic@gmail.com 